\title{
The Effect of Residues of Plant Rotation Patterns with Cover Crop Legums on Soil Organic Carbon Dynamics and Corn Products During Two Seasons of Planting
}

\author{
Rupa Matheus ${ }^{1 *}$, Donatus Kantur ${ }^{2}$, Masria $^{3}$ \\ ${ }^{123}$ Departemen of Dryland Agriculture Management, State Agricultural Polytechnic \\ Kupang, Indonesia \\ *Corresponding author'ss email: matheusrupa [AT] yahoo.com
}

\begin{abstract}
This study aimed to estimate wherewith the residual effect of the crop rotation pattern with the cover crop lagoon on the dynamics of soil organic carbon and maize yield during the two growing seasons in the Kupang region of Indonesia. The treatments evaluated were: maize rotation pattern with several types of seasonal legume cover crops and how to return the legume biomass. The results showed a very significant increase in soil organic carbon and maize yield. The rotation pattern with legumes $P$. lunatus, $M$. pririens and $C$. juncea had a statistically significant effect on increasing soil organic carbon storage and maize yield during the two growing seasons. These three types of legumes still have a positive effect until the second planting season where there is an increase in soil organic carbon storage (at a depth of 0-30 cm) of 0.75-1.19\% C-organic (82.08 to 84.38 t.hat soil carbon storage) compared to C.chayan and control treatment which decreased soil organic carbon storage was greater. About maize yields, up to PS- 2 still showed relatively stable results, namely only a decrease in maize yield $\left(\mathrm{kg}^{\left.-h a^{-1}\right)}\right.$ of $3.14 \%-4.19 \%$ compared to C. chayan which decreased yields of $15 \%$ and without control rotation) with a reduction in yield of up to $30 \%$. The method of restoring the cover crop legume biomass with the mulching technique was able to increase soil organic carbon storage by $0.71 \%$, and the yield of dry shelled maize ( $\mathrm{kg} . \mathrm{ha}^{-1}$ ) on PS-2 only decreased yield by $2.48 \%$ compared to the immersion method which reduced the yield up to $11,02 \%$. This study found that the rotation pattern does not need to be done every planting season. Still, it is sufficient to do it in intervals of two to three growing seasons. The residual effect can significantly guarantee the maintenance of organic carbon stocks in the soil. With the assurance of soil organic carbon stores coupled with proper management, soil productivity is maintained and sustainable. When soil organic carbon increases, it can benefit maize and other food crops.
\end{abstract}

Keywords--- Rotation pattern, residual effect, Legumes cover crop, soil organic carbon, Corn Results

\section{INTRODUCTION}

Carbon (C) soil is one of the essential indicators of soil quality because of its role in determining the physical, chemical, and biological properties of the soil [1,2,3,4]. The Soil has high potential in carbon sequestration because it can contribute to agronomic, physiological efficiency and is essential in the recovery of nitrogen, phosphorus, and potassium [5]. Besides, carbon (C) soil, functions as a source (source) and absorbent (sink) of nutrients for plant growth and as a substrate for soil microbes [6,7]. Increased storage of organic carbon in the soil, can directly increase the population and diversity of soil microorganisms, playing an important role in the food chain [8] and nutrient cycles in the soil [9].

At present many productive agricultural lands have been degraded due to intensive farming patterns with continuous planting and erosion factors that cause a decline in agricultural land fertility. One characteristic of the decline in soil fertility is the low organic soil carbon, which is in the range $<1.79 \%$ [10]. To maintain soil quality, soil carbon stocks must be in optimal condition through crop residue management or crop rotation patterns. Utilization of food crops and ground cover legumes as green fertilizer in crop rotation patterns can be an alternative to be a choice between food plants and local green fertilizers as soil fertility plants from the tropical ground cover legume group.

The use of tropical ground cover legumes has been practiced in plantation areas. The main objective is for conservation and soil fertility in the plantation area because it has a high biomass production and as a source of quality organic material. This pattern provides an additional advantage, which can reduce the growth of weeds and as a source of natural nitrogen fertilizer. However, this pattern has not been widely adopted by food crop farmers. Thus, innovation is needed through land rotation patterns between food crops and annual land cover legumes. The implementation can be done by introducing the annual ground cover legume in the farm, ahead of harvesting annual food crops to restore natural soil fertility during the dry season. Through land cover during the dry season by legume biomass, the physical condition of the soil remains maintained in a sustainable manner [9]. Research on the potential of ground cover legumes as fallow plants in 
the dryland farming system, significantly increased soil C-organic storage and dry shelled corn yield by $65 \%$ in the first planting season (PS-1) [10]. This study aims to determine the rotation pattern of food crops with legume cover crops and the effect of residues on the dynamics of soil organic carbon and corn yields during the two growing seasons.

\section{MATERIAL AND METHODS}

\subsection{Study Area}

The field experiment was carried out on farmers' land in Fatukanutu Village, Kupang regency, East Nusa Tenggara, Indonesia. The experiment's location is a land that is continuously planted with corn ( +5 years). Field trials last for 2 (two) years, namely: planting season 1 (PS-1) 2017/2018 and planting season 2 (PS-2) : 2018/2019. The test site is located at coordinates $10^{\circ} 10$ '23.19' 'North Latitude and $123^{\circ} 53^{\prime} 17.49$ " Southern latitude, tropical climate with total rainfall of 1,500 $\mathrm{mm} /$ year, an annual average temperature of $28^{\circ} \mathrm{C}$. The land used in this experiment was degraded upland land because planting was carried out continuously. Previous food plants are corn plants. This type of soil experiment is Vertisols which has characteristics: $72.74 \%$ clay content (clay loam), C-organic 1.56\% (low) pH 7.25 (neutral), $\mathrm{N}$ total $0.16 \%$ (low) and ratio $\mathrm{C}: \mathrm{N}$ is 9.75 .

\subsection{Research design}

This study uses a Split Plot Design, with two factors, the main plot is the land rotation pattern (L), with five types of legume cover crop (LCC) as treatment, L0: No rotation; L1: rotation with Phaseolus lunatus; L2: rotation with Mucuna pruriens; L3: rotation with Crotalaria juncea; L4: rotation with Chajanus cajan. The technique of returning cover crop legume biomass placed as a subplot with two treatments, R1: LCC biomass is buried in soil and R2: LCC biomass is returned as mulch. The experiment was repeated three times for each treatment so that in total, there were 36 experimental units.

The LCC are planted before the harvest of the corn crop and are allowed to grow for eight months (April-October 2017), as shown in Figure 1. Furthermore, the legume cover crop biomass in each plot is harvested, cut into $3-5 \mathrm{~cm}$ long, and returned according to the treatment of subplots. This is done by immersing it during tillage and turning it into mulch.

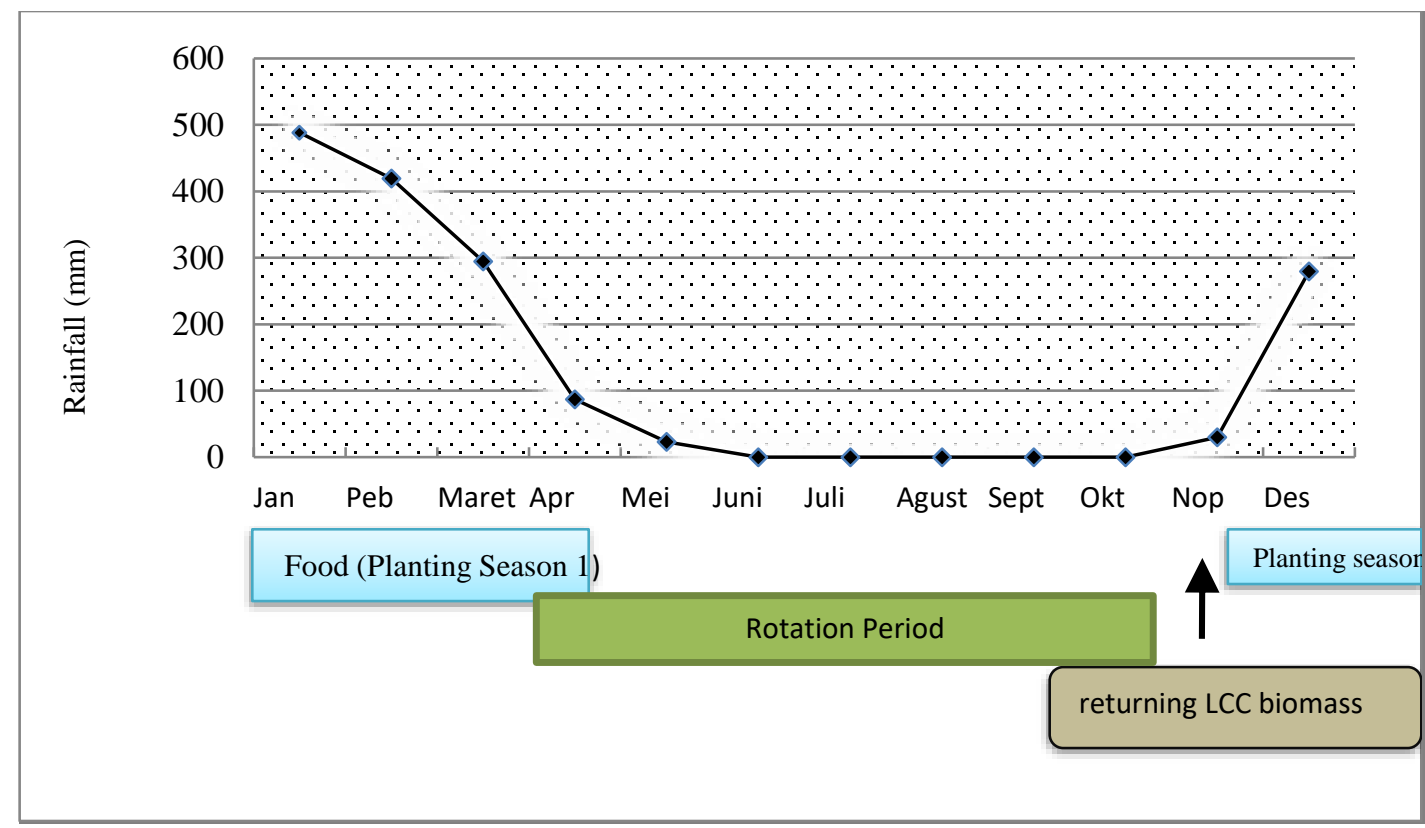

Figure 1. Model / pattern of land rotation between food crops and legume cover crops (LCC)

\subsection{Observation of Soil Samples and Corn Products}

Soil sample observations were carried out during the two growing seasons (Planting Seasons 1 and 2), aiming to determine the residual effects of the biomass legume cover crop on the dynamics of soil organic carbon and changes in carbon storage and corn yield. Composite soil samples were taken at three points at a depth of 0-30 cm in five replications in each experimental plot and analyzed in the laboratory. Measurements were made of soil organic carbon content (Walkley and Black method), total N (Kjedal method), Bulk soil density (gravimetric method), and pore size distribution using the Pressure Plate apparatus method at $\mathrm{pF}$ 1, $\mathrm{pF}$ 2, $\mathrm{pF}$ 2, 54 and $\mathrm{pF} 4.2$ (Equation of capillarity and pF curves) [11]. Soil organic carbon deposits (SOCS) are calculated using the equation: SOC stock (t.ha $\left.{ }^{-1}\right)=\mathrm{BD} \times \mathrm{SOC} \times \mathrm{DP} \times \mathrm{A}$, where $\mathrm{BD}$ is the soil 
bulk density (g / cm3); SOC is soil organic carbon content (\%); DP is soil depth (m); A is the area (ha) [12; 13]. Changes in corn production $\left(\mathrm{kg} \cdot \mathrm{ha}^{-1}\right)$ and C-Organic Deposits $\left(\mathrm{Kg} \mathrm{ha}^{-1}\right)$ are obtained from the difference between the measurement results on planting seasons 1 and 2

\subsection{Statistical analysis}

Data were analyzed using analysis of variance (ANOVA) with a confidence interval of $95 \%$. To see the effect of the real difference from the treatment variables, Duncan's multiple range test was carried out at $5 \%$ significance level (Gomez and Gomez, 2007). Data is processed using the Costat statistical program.

\section{RESULTS AND DISCUSSION}

\section{Results}

\subsection{Soil properties}

In general, land rotation patterns with several types of legume cover crop during fallow and residual effects have different effects on physical and chemical soil properties observed at the end on planting seasons 1 and 2 (Table 1),

Table 1. Effects of land rotation patterns with several types of legume cover crop (LCC) and residual effects on some soil properties

\begin{tabular}{|c|c|c|c|c|c|}
\hline \multirow{3}{*}{ Rotation System } & \multicolumn{4}{|c|}{ Physical properties } & \multirow{2}{*}{ N-Total } \\
\hline & Bulk Density & Porosity & Macropore & Micropore & \\
\hline & $. . \mathrm{g} \mathrm{cm}^{-3} .$. & & $\ldots . . . \% \mathrm{Vol} \ldots$ & & $\ldots \% \ldots$ \\
\hline Types of LCC & \multicolumn{5}{|c|}{ Planting Season 1 (PS-1, 2017/2018) } \\
\hline No rotation & $1.22^{\mathrm{a}}$ & $53.08^{c}$ & $11.45^{\mathrm{a}}$ & $9.42^{\mathrm{a}}$ & $0.15^{\mathrm{c}}$ \\
\hline P. lunatus & $1.09^{c}$ & $58.00^{\mathrm{a}}$ & $6.15^{\mathrm{c}}$ & $5.77^{\mathrm{c}}$ & $0.48^{\mathrm{a}}$ \\
\hline M. pruriens & $1.08^{\mathrm{c}}$ & $58.28^{\mathrm{a}}$ & $6.05^{\mathrm{c}}$ & $5.3^{\mathrm{c}}$ & $0.49^{\mathrm{a}}$ \\
\hline C. juncea & $1.10^{\mathrm{c}}$ & $57.10^{\mathrm{a}}$ & $7.38^{\mathrm{c}}$ & $6.53^{\mathrm{bc}}$ & $0.51^{\mathrm{a}}$ \\
\hline C. chajan & $1.17^{\mathrm{b}}$ & $55.10^{\mathrm{b}}$ & $9.05^{\mathrm{b}}$ & $7.74^{\mathrm{b}}$ & $0.30^{\mathrm{b}}$ \\
\hline \multicolumn{6}{|l|}{ Technique of returning: } \\
\hline Buried in soil & $1.12^{\mathrm{a}}$ & $57.1^{0 \mathrm{a}}$ & $8.42^{\mathrm{a}}$ & $7.64^{\mathrm{a}}$ & $0.40^{\mathrm{a}}$ \\
\hline Returned as mulch & $1.15^{\mathrm{a}}$ & $55.85^{\mathrm{a}}$ & $7.62^{\mathrm{a}}$ & $6.27^{\mathrm{a}}$ & $0.3^{7 \mathrm{a}}$ \\
\hline Types of LCC: & \multicolumn{5}{|c|}{ Planting Season 2 (PS-2, 2018/2019 } \\
\hline No rotation & $1.25^{\mathrm{a}}$ & $52.06^{\mathrm{c}}$ & $12.06^{\mathrm{a}}$ & $9.83^{\mathrm{a}}$ & $0.13^{\mathrm{c}}$ \\
\hline P. lunatus & $1.08^{\mathrm{c}}$ & $58.40^{\mathrm{a}}$ & $6.82^{\mathrm{c}}$ & $6.18^{c}$ & $0.41^{\mathrm{a}}$ \\
\hline M. pruriens & $1.06^{\mathrm{c}}$ & $59.07^{\mathrm{a}}$ & $6.86^{\mathrm{c}}$ & $5.86^{\mathrm{c}}$ & $0.46^{\mathrm{a}}$ \\
\hline C. juncea & $1.11^{\mathrm{c}}$ & $57.42^{\mathrm{a}}$ & $7.80^{\mathrm{c}}$ & $6.97^{\mathrm{c}}$ & $0.50^{\mathrm{a}}$ \\
\hline C. chajan & $1.15^{\mathrm{b}}$ & $55.59^{\mathrm{b}}$ & $9.75^{\mathrm{b}}$ & $8.13^{\mathrm{ab}}$ & $0.18^{b}$ \\
\hline \multicolumn{6}{|l|}{ Technique of returning: } \\
\hline Buried in soil & $1.15^{\mathrm{a}}$ & $55.87^{\mathrm{a}}$ & $9.09^{\mathrm{a}}$ & $8.41^{\mathrm{a}}$ & $0.34^{\mathrm{a}}$ \\
\hline Returned as mulch & $1.11^{\mathrm{a}}$ & $57.14^{\mathrm{a}}$ & $8.23^{\mathrm{a}}$ & $6.37^{\mathrm{a}}$ & $0.33^{\mathrm{a}}$ \\
\hline
\end{tabular}

Note : Numbers followed by the same superscript in the same column show no significant difference at the Duncan $5 \%$ test level.

\subsection{Bulk Density and Porosity}

The soil physical analysis results show that the rotation pattern with legume cover crop and residual effects significantly influences the value of bulk density and soil porosity during the two growing seasons (PS-1 and PS-2). The rotation pattern of the P. lunatus, $M$. pruriens and $C$. juncea legumes significantly decreases the bulk density value and increases the total pore space of both PS-1 and PS-2 by an average of $1.13 \mathrm{~g} . \mathrm{cm}^{-3}$ and a total pore space of $57.96 \%$ better and compared with bulk density and total pore space achieved in C. chayan and without rotation treatment. The difference in bulk density and total pore space is also seen in the way to return the biomass legume cover crop to PS-2, where the method of return with mulch significantly decreases the bulk density by $1.11 \mathrm{~g}^{\mathrm{cm}} \mathrm{cm}^{-3}$ and increases the total pore space of the soil by $57.14 \%$ higher than by immersion.

\subsection{Pore Size Distribution}


The pore size distribution observed after rotation with the legume cover crop in this study was rapid drainage pore and available water pore. The Duncan test results (Table 1) show that the rotation pattern treatment with P. lunatus, M. pruriens and C. juncea types and their residues significantly improved pore drainage quickly to PS- 2 each by $6.82 \%, 6.86$ $\%$, and $7.80 \%$ and available water pores of $6.18 \%, 5.86 \%$ and $6.97 \%$, respectively compared to rotation with C. chayan type and without rotation. The difference between the fast drainage pore and the available water pore is also seen in the way of returning the legume cover crop biomass. The real mulch method improves rapid drainage pore of $8.23 \%$ and available water pores of $6.37 \%$ to PS-2 compared to the immersion method, which at PS-2 of $9.09 \%$ rapid drainage pores and $6.41 \%$ of available water pores.

\subsection{Nitrogen}

The rotation pattern of the legume cover crop on intensive farming land and its residue significantly affects soil nitrogen up to PS-2. The total soil nitrogen of vertisol after rotation ranges from $0.15 \%$ to $0.51 \%$ (PS-1), while in PS-2 it ranges from $0.13 \%$ (low) to $0.52 \%$ (high) or averaged to PS-2 of $0,34 \%$. The measurement results showed that the cultivated land rotated with P. lunatus, $\mathrm{M}$. pruriens, and C. juncea was significantly able to increase the total soil nitrogen until the second planting season by $0.41 \%, 0.46 \%$ and $0.50 \%$ higher than the land rotated with $\mathrm{C}$. chayan and without rotation of $0.18 \%$ and 0.13 (Table 1). The difference in total soil nitrogen was also seen in the method of returning cover crop biomass, where the technique of returning with mulch and the practice of immersion did not show a significant difference with the total soil nitrogen value up to PS-2 of $0.33 \%$ and $0.34 \%$.

\subsection{Soil Carbon Dynamics}

The land rotation pattern with the legume cover crop and its residual effect significantly increased the soil organic $\mathrm{C}$ content until the second planting season. The organic $\mathrm{C}$ content of various cover crop legumes was substantially different from one another (Figure 2).

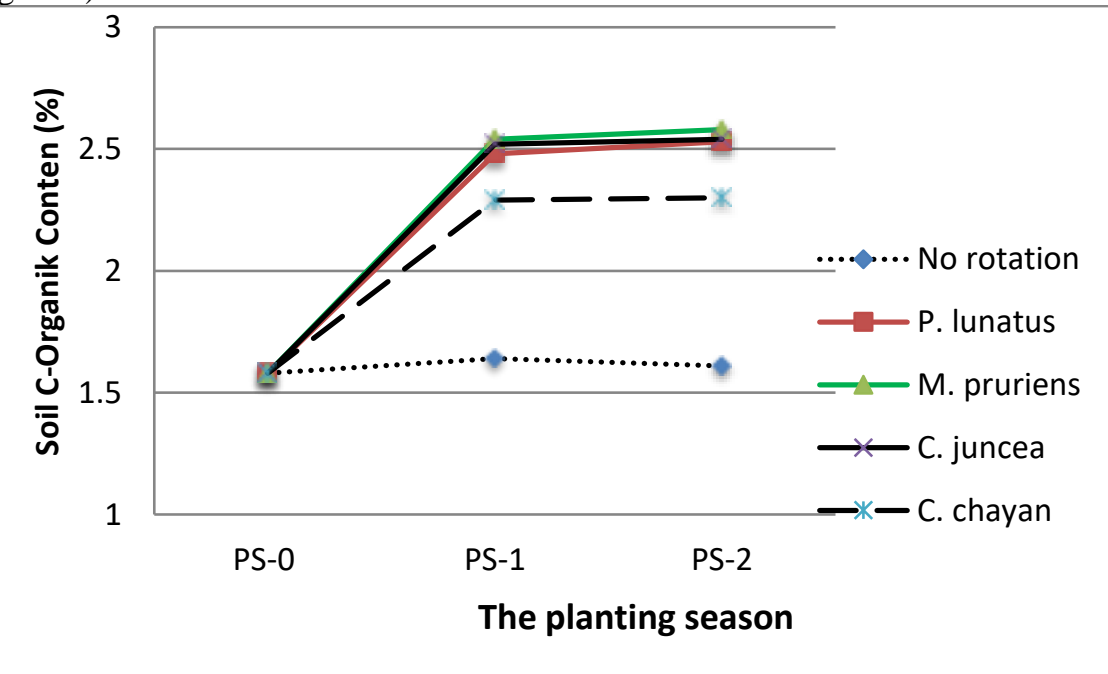

Figure 2. Dynamics of C-Organic Content of Soil Due to Rotation Patterns with legume cover crop.

Note: PS-0: C-organic content before rotation; PS-1: C-organic content in the land after rotating with the legume cover crop, then planting corn (PS-1); PS-2: C-organic content in the same land after planting corn in the next growing season (PS-2).

Observation of post-rotation soil organic carbon with ground cover legumes is essential because soil organic carbon is the primary indicator of soil quality. This measurement determines whether there is still an effect from the biomass residue of the cover crop legume on the soil organic $\mathrm{C}$ content until the second planting season. Soil samples were taken at a depth of 0-30 cm. Figure 2 shows that the land rotation pattern with the legume species P. lunatus, M. pruriens, and $\mathrm{C}$. juncea and their residual effects were still able to maintain organic carbon levels of $2.53 \%, 2.58 \%$, and $2.54 \%$, respectively. Compared without rotation and rotation patterns with the legume species $\mathrm{C}$. chayan and without rotation with a lower soil carbon content.

\subsection{Changes in Organic Carbon Storage and Maize Yield after rotation with cover crop}

The results showed that there was a residual effect from the rotation pattern with the legume cover crop on changes in soil organic carbon storage and maize yield during the two growing seasons (Table 2). 
Table 2. Effects of residuals from crop rotation patterns with tropical cover crop legumes on changes in organic carbon storage $\left(\mathrm{t}_{\mathrm{ha}} \mathrm{h}^{-1}\right)$ and maize yield $\left(\mathrm{kg} \cdot \mathrm{ha}^{-1}\right)$ in dryland farming systems

\begin{tabular}{|c|c|c|c|c|c|c|c|c|}
\hline \multirow[t]{2}{*}{ Rotation system } & \multicolumn{2}{|c|}{$\begin{array}{l}\text { Bulk Density } \\
\left(\mathrm{g} / \mathrm{cm}^{3}\right)\end{array}$} & \multicolumn{2}{|c|}{ SOC Stock (t/ha) } & \multirow{2}{*}{$\begin{array}{l}\text { DfC* } \\
\text { (t/ha) }\end{array}$} & \multicolumn{2}{|c|}{ Yied corn $(\mathrm{kg} / \mathrm{ha})$} & \multirow{2}{*}{$\begin{array}{l}\text { DfY* } \\
(\mathrm{kg} / \mathrm{ha})\end{array}$} \\
\hline & PS- 1 & PS-2 & PS-1 & PS-2 & & PS-1 & PS-1 & \\
\hline \multicolumn{9}{|l|}{ Types of LCC: } \\
\hline No rotation & $1.22^{\mathrm{a}}$ & $1.25^{\mathrm{a}}$ & $59.90^{c}$ & $60.21^{\mathrm{c}}$ & -0.31 & $3.256^{\mathrm{c}}$ & $2.276^{\mathrm{c}}$ & -980 \\
\hline P. lunatus & $1.09^{c}$ & $1.08^{c}$ & $81.31^{\mathrm{a}}$ & $82.08^{a}$ & +0.77 & $5.918^{a}$ & $5.698^{a}$ & -220 \\
\hline M. pruriens & $1.08^{c}$ & $1.06^{\mathrm{c}}$ & $82.68^{a}$ & $82.07^{\mathrm{a}}$ & +0.61 & $6.200^{\mathrm{a}}$ & $5.940^{\mathrm{a}}$ & -260 \\
\hline C. juncea & $1.10^{\mathrm{c}}$ & $1.11^{\mathrm{c}}$ & $83.39^{\mathrm{a}}$ & $84.38^{\mathrm{a}}$ & +0.99 & $6.291^{\mathrm{a}}$ & $6.093^{\mathrm{a}}$ & -198 \\
\hline C. cayan & $1.17^{\mathrm{b}}$ & $1.15^{\mathrm{b}}$ & $80.06^{\mathrm{b}}$ & $79.64^{\mathrm{b}}$ & -0.42 & $5.161^{\mathrm{ab}}$ & $4.366^{\mathrm{b}}$ & -795 \\
\hline \multicolumn{9}{|l|}{ Technique of returning: } \\
\hline Buried in soil & $1.12^{\mathrm{a}}$ & $1.15^{\mathrm{a}}$ & $77.65^{\mathrm{a}}$ & $77.59^{\mathrm{b}}$ & -0.06 & $5.361^{\mathrm{a}}$ & $4.770^{\mathrm{b}}$ & -591 \\
\hline Returned as mulch & $1.15^{\mathrm{a}}$ & $1.11^{\mathrm{a}}$ & $77.29^{\mathrm{a}}$ & $77.84^{\mathrm{a}}$ & +0.55 & $5.270^{\mathrm{a}}$ & $5.139^{\mathrm{a}}$ & -131 \\
\hline
\end{tabular}

Note: The number followed by the same superscript letter in the same column shows no significant difference at the Duncan test level of $5 \%$

* DfC: change in soil organic carbon storage; * DfY: Change in corn yield

This study showed that the residual effect of the rotation pattern with the legume species P. lunatus, M. prurien and C. juncea was the occurrence of significant changes in soil organic carbon storage and maize yield between PS-1 and PS-2 (Table 2). Soil organic carbon storage (Table 2) shows a considerable difference between PS-1 and PS-2. Rotation pattern with a legume P. lunatus. M. prurien and C. juncea were able to increase soil organic carbon storage up to PS-2, namely an increase of 0.77 tonnes/ha, 0.61 ton/ha, and 0.99 ton/ha, respectively, compared to the treatment of C. chayan decreased by 0.42 ton/ha and without rotation, decreased C-organic storage by 0.31 ton/ha. The treatment of returning biomass using mulch showed an increase in soil organic carbon storage by 0.55 tonnes/ha, higher than the immersion method, which decreased carbon storage by 0.06 tonnes/ha on PS-2.

Rotation pattern with P. lunatus, M. prurien, and C. juncea on PS-1 gave smaller changes in maize yields, namely $220 \mathrm{~kg} / \mathrm{ha}, 260 \mathrm{~kg} / \mathrm{ha}$, and $198 \mathrm{~kg} / \mathrm{ha}$ respectively, compared to C. cayan and without rotation with yields reaching 395 $\mathrm{kg} / \mathrm{ha}$ and $980 \mathrm{~kg} / \mathrm{ha}$. The same thing was seen in the treatment of return of cover crop biomass as mulch, where there was a smaller yield change of $131 \mathrm{~kg} / \mathrm{ha}$ compared to the immersion method, which showed a difference in yield of $591 \mathrm{~kg} / \mathrm{ha}$.

\section{Discussion}

Overall, the land rotation pattern with the legume cover crop, LCC (as in Figure 1) has a significant effect, namely an increase in land productivity from before rotation. The rotation pattern with the legume species P. lunatus, M. pruriens, and $\mathrm{C}$. juncea significantly improved soil properties (physical and chemical), increased levels of organic C, and maize yields than the residue of $\mathrm{C}$. chayan and control treatments (no rotation). This is influenced by the quantity and quality of the cover crop legume biomass introduced in better-cultivated land. From the quality aspect, it can be seen that the three types of legume cover crops have better biomass quality, namely a low $\mathrm{C} / \mathrm{N}$ ratio (average +9.37 ), with the content of organic compounds, namely lignin content, looks smaller on average. $+9.64 \%$ [14] below the critical point of $<15 \%$ [14, $15,16]$. Meanwhile, polyphenols were higher by an average of 5.87\% [14] above the critical limit, namely> 4\% [15,16]. The content of lignin and polyphenols is a determining parameter for the quality of organic matter. It plays a role in determining whether or not the organic matter is easily broken down by soil microbes $[15,16]$. The quality of the LCC biomass affects the rate of decomposition [17]. Apart from quality, the three types of cover crop legume also have a larger biomass product with a dense and thick leaf crown so that they can cover the soil surface during fallow. The impact is that soil moisture is always maintained during the fallow period so that soil microbial activity in decomposing fallen plant litter continues.

The soil in the research location is dominated by clay fraction, which can inhibit the rate of aeration and drainage in the soil, which results in low soil productivity. Thus, innovation in improving the physical quality of the soil through a rotation pattern is an easy and inexpensive solution. The rotation pattern of the legume cover crop during the fallow period and the biomass back to the land has an impact on soil carbon dynamics (Figure 2), which indicates a significant difference between the types of cover crop legume. Soil organic carbon is a determining indicator of soil quality and health [1,2]. This is because soil organic carbon (C-organic) is one of the essential soil components in the soil ecosystem, namely as a source and sink, and as a substrate for soil microbes [18]. The presence of organic carburetor in the soil layer will improve aggregation, especially soils with a clay texture. With the increase in soil organic carbon, the opportunity for water stress to occur is small, because the range of soil water content that can be used by plants is greater. This condition is very important in dryland farming, which often experiences drought stress. Increased soil aggregation affects improving physical properties, reducing bulk density, and increasing pore space and soil pore distribution. The soil pore system is strongly influenced by soil organic matter, clay type and content, moisture, compaction, and soil management [19]. The pore size 
distribution is a combination of soil texture and structure. Soils that are dominated by clay fraction will have many micropores (small) or are not porous.

Changes in soil organic carbon storage (ton.ha ${ }^{-1}$ ) (Table 2) were determined from three main variables that are interrelated (not independent), namely soil organic carbon concentration (C\%), bulk density (BD) (g.cm ${ }^{-3}$ ), and soil depth $(\mathrm{cm})$. The study (in this study) show that the rotation pattern with the legume species P. lunatus, M. pruriens, and C. juncea, can increase the cumulative soil organic carbon storage at a depth of $0-30 \mathrm{~cm}$ by an average of $38.30 \%$ compared to without rotation. This result is consistent with the explanation that about half $(50 \%)$ of soil organic carbon is in the $0-30 \mathrm{~cm}$ layer at $0-100 \mathrm{~cm}$ soil depth $[20,21]$. In this research, there was also a change in carbon storage, namely an increase of $0.75-$ $1.19 \%$ (82.08-84.38 ton.ha ${ }^{-1}$ of soil carbon storage). Changes in soil organic carbon storage affect soil productivity due to the influence of different factors, including the transformation of atmospheric carbon net flux into green plants per unit time, and plant root patterns [22]; quality of organic matter supply [23]; Certain soil properties (nutrient availability, soil physical properties) [24], and past and present management intensity [25].

The method of returning biomass using mulching shows a positive change in soil organic carbon storage, namely an increase in carbon by 0.55 ton.ha ${ }^{-1}$ compared to the immersion method. This is because using mulching, the decomposition of plant biomass (fresh organic matter) by soil organisms will be slower and longer. Using mulching, organic matter, which is the main energy source for soil microbes, remains available for a relatively long time. The availability of organic matter will help soil microorganisms' activities in decomposition and mineralization, so that the release of carbon from other organic compounds takes place slowly, remains stored in the soil layer, and is not easily eroded or washed into deeper soil layers.

\section{CONCLUSION}

1. The land rotation pattern with the type of legume cover crop and its residual effect is having a significant impact on soil properties and soil carbon dynamics during the two planting seasons.

2. P. lunatus, M. pruriens and C. juncea, gave a positive effect on increasing soil organic carbon storage (at a depth of 0-30 cm) by $0.75-1.19 \%(82.08-84.38 \mathrm{t} /$ ha $)$ until the second planting season compared to C.chayan and control which caused a decrease in soil organic carbon storage.

3. Treatment without rotation (control) decreased the highest maize yield by $30 \%$, followed by C. chayan treatment by $15 \%$. In contrast, the treatment of P. lunatus, M. pruriens, and C. juncea only experienced a decrease in yield of 3-14$4.19 \%$.

4. The method of restoring the legume cover crop biomass with the mulching technique increased soil organic carbon storage by $0.71 \%$ from the immersion method.

\section{ACKNOWLEDGMENTS}

We would like to thank the Directorate of Research and Community Service of the Ministry of Research, Technology and Higher Education who has funded this research for three years (2016 - 2019) and the Kupang State Agricultural Polytechnic Research and Community Service Center who facilitated this research.

\section{REFERENCES}

[1] Islam, K.R dan Weil. 2000. Soil quality indicator properties in mid-atlantic soils as influenced by conservation management. J. Soil and Water Cons. 55 (1) : 69-78.

[2] Laishram, K.G. Sexana, R.K. Maikhu and K.S. Rao. 2012. Soil Quality and Soil Health: A Review. International Journal of Ecology and Envirinmental Science, Vol 38 (1): 19-37

[3] Huang, Z., Davis, M.R., Condron, L.M., \& Clinton, P.W. (2011). Soil carbon pools, plant biomarkers and mean carbon residence time after afforestation of grassland with three tree species. Soil Biol. Biochem. 43, 1341-1349

[4] Liu, X., Herbert, S.J., Hashemi, A.M. Zhang, X., Ding, G. 2006. Effects of agricultural management on soil organic matter and carbon transformation-a review. Plant. Soil Environ. 56(12): 531-543

[5] Rahman, M.M. 2013. Nutrient-Use and Carbon-Sequestration Efficiencies in Soils from Different Organic Wastes. In: Rice and Tomato Cultivation. Comm. in Soil Sci. and Plant Anal., 44 (9): 1457-1471.

[6] Lal, R; Kimble, J.M., Follett, R. F., Stewart, H.A. 2001. Assesment method for soil carbon. Lewis Publisher. 676p

[7] Kimble, J.M., Lal, R., Ruttan, L., Folett, R. F. 2002. Agricultural Practices and Polices for Carbon Sequestration in Soil. Lewis Publisher. 512p

[8] Kiriya Sungthongwises, Anan Wongcharoen and Chutinan Choosai. 2020. Phospate Solubilisation and indole Acid Production by Bacteria Isolated From Root System of Dipterocarpus. Asian Journal of Plant Science, Vo. 19 (1): 8 13

[9] Matheus, 2019. Skenario Pengelolaan Sumber Daya Lahan Kering: Menuju Pertanian Berkelanjutan. Penerbit Deepublish. Yogyakarta. 
[10] Matheus, R., Donatus Kantur, and Naema Bora. 2018. Innovation Of The Fallow System With The Legume Cover Crop A Season For Improved Physical Properties Of Soil Degradated On Dryland Farming. Inyetnational of Scientific \& Technology Research. Vol. 7 (7) 107-111.

[11] Danielson, R.E. and P.L. Sutherland. 1986. Porosity, pp. 443-461. In Methods of soil analysis. Part 1. Physical and mineralogical methods. Agronomy monograph No 9. American Society of Agronomy, Soil Science Society of America. Madison, Wisconsin

[12] Shofiyati, R., I. Las, and F. Agus. 2010. Indonesian soil database and predicted stock of soil carbon. Proceedings of International Workshop on Evaluation and Sustainable Management of Soil Carbon Sequestration in Asian Countries, Bogor, Indonesia, 28-29 September 2010.

[13] Komatsuzaki,M., Syaib, M.F. 2010. Comparison of the Faring System and Carbon Sequestration between Conventional and Organic Rice Production in West Java, Indonesia. 933p

[14] Matheus, D. Kantur, N. Bora. 2018. Innovation Of The Fallow System With The Legume Cover Crop A Season For Improved Physical Properties Of Soil Degradated On Dryland Farming. Journal of Scientific \& Technology Research. Vol. 7 (7)1: 107-111. https://www.ijstr.org/research-paper-publishing.php?month=july2018

[15] Stevenson FJ. 1994. Humus Chemistry. Genesis, Composition, Reaction. 2nd ed. John Wiley and Sons. New York

[16] Handayanto, E., Cadisch, G., Giller., K. E. 1997. Regulating N Mineralization from Plant Recidues by Manipulation of Quality. P.175-185. In: G. Grdisch and K.E. Giller (eds.). Driven by nature plant litter quality and decompocition $C A B$ International, Wallingford.

[17] Matheus, R.., Suwardji., Nurjaya, IG.M.O., dan Agung, I G.A.M.S. 2013. Rates Of Decomposition And Nutrient Release From Biomass Of Various Species Of Tropical Legume Cover Crops In Dryland Soils Of Eastern Indonesia. Journal of Biology, Agriculture and Healthcare. Vol. 13 (16):107-114. http://www.iiste.org/Journals/index.php/JBAH/article/view/8243/8634.pdf.

[18] Matheus, R. 2014. Peran Legum penutup tanah tropis dalam menimgkatkan simpanan karbon organik tanah dan Kualitas tanah serta Hasil jagung (Zea maiz L) di lahan kering. Disertasi. Universitas DUdayana. Dempasar.

[19] Wairiu, M. and Lal, R. 2006. Tillage and land use effects on soil microporosity in Ohio, USA and Kolombangara, Solomon Islands. Soil Till. Res. 88: 80- 84

[20] IPCC. (2006). Agriculture, forestry and other land use. In S. Eggleston, L. Buendia, K. Miwa, T. Ngara, \& K. Tanabe (Eds.) Guidelines for National Greenhouse Gas Inventories (Vol. 4). IGES, Japan

[21] Batjes, N.H. (1996). Total carbon and nitrogen in the soils of the world. European Journal of Soil Sci. 47(2), 151163

[22] Jobbágy, E.G. \& Jackson, R.B. (2000). The vertical distribution of soil organic carbon and its relation to climate and vegetation. Ecol. Appl. 10, 423-436

[23] Berg, B., Johansson, M.B., Nilsson, A., Gundersen, P., \& Norell, L. (2009). Sequestration of carbon in the humus layer of Swedish forests-direct measurements. Can. J. For. Res. 39, 962-975

[24] Mendham, D.S., O’Connell, A.M., \& Grove, T.S. (2003). Change in soil carbon after land clearing or afforestation in highly weathered lateritic and sandy soils of southwestern Australia. Agriculture, Ecosystems \& Environment 95(1), 143- 156.

[25] Balesdent, J., Chenu, C., \& Balabane, M. (2000). Relationship of soil organic matter dynamics to physical protecttion and tillage. Soil Tillage Res. 53, 215-230. 